RESEARCH

\title{
CONTRIBUTIONS OF AMERICAN DESCRIPTIVE LINGUISTIC SCHOOL TO THE STUDY OF VIETNAMESE: A CONTEMPORARY LOOK
}

\author{
Hoang Van Van* \\ Center of Foreign Language Education Research, Linguistics and International Studies, VNU \\ University of Languages and International Studies, Pham Van Dong, Cau Giay, Hanoi, Vietnam
}

Received 21 July 2020

Revised 1 September 2020; Accepted 14 October 2020

\begin{abstract}
This article examines the contributions of the American descriptive linguistic school in the mid- $20^{\text {th }}$ century to the study of Vietnamese. Two most important monographs on Vietnamese grammar by two foremost American descriptivist/structuralist grammarians were taken for examination: Studies in Vietnamese (Annamese) Grammar by Murray B. Emeneau and A Vietnamese Reference Grammar by Laurence $\mathrm{C}$. Thompson. It is clear that among the foreign scholars who have studied Vietnamese, Emeneau and Thompson have made the most substantial contributions to the study of Vietnamese grammar. They both have made a major point in seeking to analyse Vietnamese on the basis of Vietnamese alone, trying to avoid as much as possible any distortion from Indo-European grammatical concepts; and thus have produced good and reliable results. Their descriptive works on Vietnamese are detailed and systematic, meeting most of the criteria of a standard grammar: meticulousness, comprehensiveness, lucidity, rigor, and elegance. Together with the studies of Vietnamese grammar by grammarians of other linguistic traditions, either indigenous or foreign, their works have enriched our ways of looking at language, broadening our understanding of one of the most fruitful approaches to the study of Vietnamese grammar.
\end{abstract}

Keywords: American descriptive linguistic school, Vietnamese language, Vietnamese grammar, Emeneau, Thompson

\section{Introduction}

In his research on the influence of different linguistic schools/approaches to the study of Vietnamese, Hoang Van Van (2012) divides the study of Vietnamese grammar into three main periods: the first period, referred to as 'protogrammatics of Vietnamese', starts roughly from the early 1860s (the time the French invaded Vietnam) through to the 1930s; the second period - 'the transitional stage' lasts

* Tel.: 84-946296999,

Email: vanhv@vnu.edu.vn; vanhv.sdh@gmail.com around the late 1940s up to the end of the 1980s; and the third period - 'the functional descriptions of Vietnamese' brings us to the present. Of the three periods, the transitional period is perhaps the most vigorous and exciting one. It is characterized by the diversity of approaches to the description of Vietnamese. It is no exaggeration to say that almost all the 'isms' in world linguistics can be found in the works of scholars studying Vietnamese in this period. On the one hand, one may note that French traditional approach to language study still existed in a number of early grammars 
(e.g. Pham Tat Dac, 1950; Tran Trong Kim et al., 1940; Nguyen Truc Thanh, 1956; Bui Duc Tinh, 1952). On the other hand, the imprint of French structuralism and Russian formalism could be found in the writings of Vietnamese as well as Russian scholars studying Vietnamese (e.g. Nguyen Tai Can, 1975a, 1975b; Truong Van Chinh and Nguyen Hien Le, 1963; Le Van Ly, 1948; Solntsev et al., 1960; Nguyen Kim Than, 1977; UBKHXH, 1983) while American descriptivism or the American structuralist approach greatly influenced the work of at least some southern Vietnamese and American grammarians of Vietnamese. A brief account of the "isms" that are supposed to have influenced the study of Vietnamese grammar would be useful but would go beyond the scope of this paper. The point of reference for these schools of linguistics is to be found in such volumes as Schools of Linguistics by Sampson (1980) and A Short History of Linguistics by Robins (1997, 2012), and An Experiential Grammar of the Vietnamese Clause by Hoang Van Van (2012). In what follows, I shall be specifically concerned with discussing the contributions made by American descriptive linguistic school to the study of Vietnamese grammar. Two questions raised for exploration are, "How is Vietnamese anatomized by grammarians of American descriptive linguistic school?", and "What contributions do they make to the description of Vietnamese grammar?" Among the various American scholars who have studied Vietnamese, Murray B. Emeneau and Laurence $\mathrm{C}$. Thompson are the foremost writers. It is their works on Vietnamese grammar that we shall consider below.

\section{Murray B. Emeneau}

In the late 1930s, the US Government suddenly became involved in distant countries, including Vietnam. A number of American linguists and foreign language teachers were called in to organize programmes for teaching the 'unusual' languages (Spolsky, 1997, p. 326) of the distant countries. Right in the mid-1940s, Vietnamese language courses were offered at various American universities such as Cornell, Columbia, Yale, and Georgetown, especially at the Defense Language Institute of the US Department of Defense. One of the first American scholars who was asked to perform this task of preparing materials for teaching Vietnamese language was perhaps Murray B. Emeneau. His book entitled Studies in Vietnamese (Annamese) Grammar was published by the University of California Press in 1951. The book was the result of Emeneau's teaching materials prepared for an Army Specialized Training Course. The preparation of the materials lasted for a year and a half: from mid-1943 to the end of 1944. The course was produced by the "ditto" process in two volumes which Emeneau was a co-author: A Course in Annamese coauthored with Diether von den Steinen and $A n$ Annamese Reader co-authored with Diether von den Steinen and Ly Duc Lam.

In Studies in Vietnamese (Annamese) Grammar, Emeneau employs analytic tools developed by American descriptive linguists (e.g. Boas, 1911; Bloomfield, 1933; Gleason, 1955; Harris, 1951; Hockett, 1958, and others) to describe and analyse Vietnamese grammar. He takes Vinh dialect (a dialect in central Vietnam) and Tonkinese dialect (a dialect in Northern Vietnam) as the objects of description. He uses a corpus of 2025 basic Vietnamese words as source of data for illustration, and two informants, one speaking Vinh dialect and the other speaking Northern Vietnamese dialect, as sources of reference to check the validity of his description and explanation. 
It should be noted that right from the second half of the $19^{\text {th }}$ century and the early $20^{\text {th }}$ century, French scholars such as Aubaret (1864), Bouchet (1912), Grammont and Le Quang Trinh (1911), Léon (1885), Vatlot (1897), and others, while studying the Vietnamese language, started to realize that many language features and grammatical categories of French did not have equivalents in Vietnamese. Thus, questioning whether there existed parts of speech in Vietnamese, Grammont and Le Quang Trinh remarked:

In Vietnamese there are no articles, nouns, pronouns, verbs; there are no genders and numbers either, only words; these words are all monosyllabic and in general invariable; their meanings are changed and determined by the positions of the words which precede or follow them, i.e., by their functions or positions in the sentence. (Grammont \& Le Quang Trinh, 1911, pp. 201-2, as cited in Nguyen Kim Than, 1977, p. 14) ${ }^{1}$

Based on the studies of Vietnamese by previous scholars, especially French orientalists, and fully equipped with analytic techniques of American descriptivism combined with his natural ability to distinguish between language-universal categories and language-specific categories (for detail about the terms 'language-universal category' \& 'language-specific category', see Matthiessen, 1995; Hoang Van Van, 2012), Emeneau

\footnotetext{
${ }^{1}$ Ibid., p. 14. This passage appears in the Vietnamese original as follows: Trong tiếng Việt không có mạo từ, danh từ, đại từ, động từ, cũng không có giống, số mà chỉ có những từ không thôi; những từ này đều là đơn âm tiết, nói chung không biến đổi, ý nghĩa của chúng thay đổi hay được xác định nhờ những từ được đặt trước hay theo sau; nghĩa là, nhờ chức năng, vị trí của chúng ở trong câu.
}

develops a sound approach to the description of the Vietnamese - an alien language to him by then. He states:

In a language with no inflection, all of whose grammar has to be presented in syntactical statements, every word must be examined in as many constructions as possible, and constant reference to a native speaker is necessary. (Emeneau, 1951, p. viii)

Emeneau's book consists of eight chapters: I. Phonology; II. Outline of the Syntax Word Classes and Types of Predication; III. Substantives; IV. Morphemes Restricted in Use; VI. Conjunctions; VII. Final Particles; and VIII. Interjections. Of these eight chapters, I and II are of immediate interest, and will be examined below.

With regard to Vietnamese phonology, Emeneau remarks:

The language gives those who are accustomed to the languages of Western Europe the general impression of being underarticulated. Although the articulations are all precise enough, the resulting sounds seem to be made with little force, very softly and gently. No detailed statements can be made at present about this quality; it does not figure at all in the phonemic statements, but it is of some importance for anyone who intends to learn the language with an acceptable pronunciation. (Emeneau, 1951, pp. 8-9)

Emeneau recognizes 11 vowel phonemes and 21 consonant phonemes in Vietnamese. Modifying somewhat to suit modern transcription symbols, these vowel and consonant phonemes can be presented in Table 1 and Table 2. 
Table 1. Vowel phonemes in Vietnamese (Emeneau, 1951, p. 19)

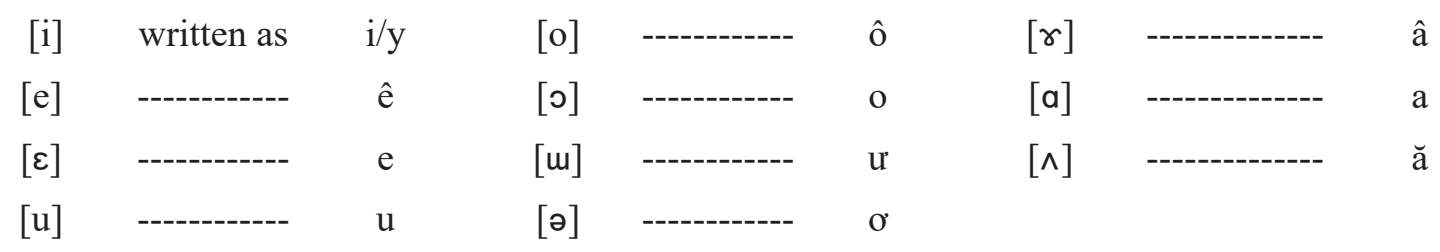

Table 2. Consonant phonemes in Vietnamese (Emeneau, 1951, p. 12)

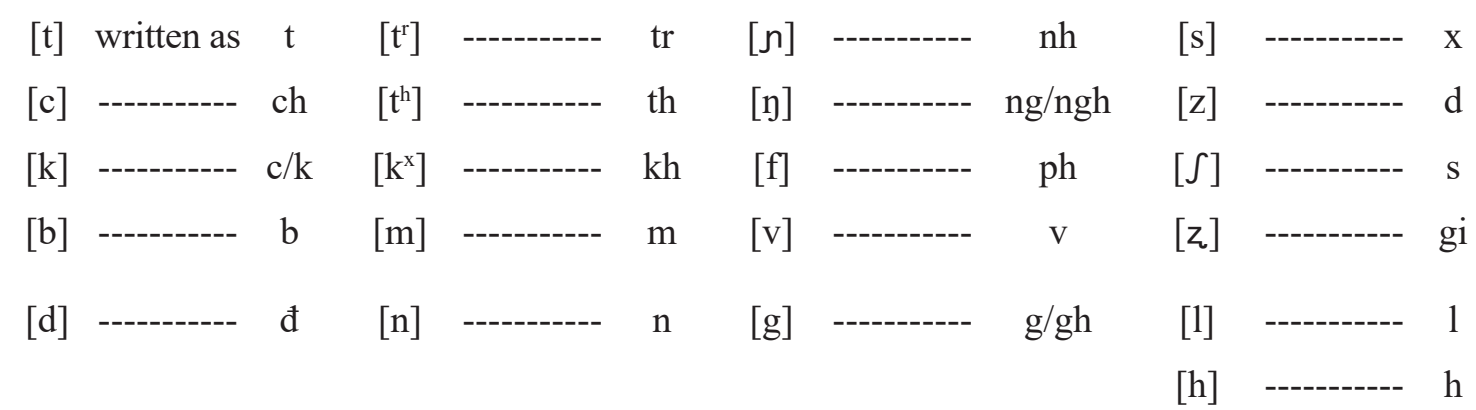

Emeneau shows a natural ability to observe the Vietnamese tone system. He recognizes six tones, stating that these six tones are phonetic as well as phonemic (p. 16). Below is Emeneau's description of the six tones in Vietnamese:

- Unmarked in writing: high level - normal voice production; on a fairly even pitch without its whole length.

- /: high rising - normal voice production; begins at about the pitch of the high level tone and rises sharply to a higher pitch.

- ।: low falling - normal voice production; falls fairly steeply in pitch.

- . : low level - normal voice production; begins on a lower pitch as a creaky falling tone and maintains a fairly even pitch throughout its whole length.

- ? : creaky falling - within the middle range; falls fairly steeply in pitch and then levels off.

- : creaky level - begins at about the same pitch as the creaky falling, though there may be slight sag in the middle.

(Emeneau, 1951, p. 8)

Having examined the vowels, the consonants, and their occurrences in the syllable, and the six tones and their occurrences in the word, Emeneau turns to Chapter II where he explores Vietnamese syntax which is organized around two headings: word classes and types of predication. In Emeneau's opinion, "The basic unit of the syntactic analysis of the language is the word which is the phonological unit and, at the same time, the morphological unit" (p. 44). Emeneau observes that in Vietnamese the word is always phonologically free, but not all of them are syntactically free. The phonological relative freedom of the word lies in that it can be described in terms of distribution of phonemes and tones. The syntactic non-freedom of some words is reflected in the fact that

Many words cannot enter freely into the normal constructions of the language but occur only in restricted co-occurrences; i.e., in construction with certain words, usually themselves similarly restricted in occurrence. (Emeneau, 1951, p. 2) 
Emeneau notes that most of the Vietnamese bound morphemes are substantives and verbs. They can be distinguished from free morphemes by the fact that they cannot be freely combined with any words of appropriate meaning and word class, but only with a limited number of words in a limited number of constructions. One of Emeneau's interesting observations is that these bound morphemes are Chinese loan words. He discusses in some detail the ordinary and restricted types of substantive and verb phrases. Their usual patterns are of three types: (i) restricted word + restricted word, (ii) restricted word + free word, and (iii) free word + restricted word (pp. 44-54). He recognises that such constructions can perform the same syntactic function as free morphemes because they can 'substitute for single word morphemes of the same class' (p. 44).

Emeneau classifies words in Vietnamese into five major word classes: (1) substantive, (2) verb, (3) conjunction, (4) final particle, and (5) interjection. Based on their occurrence in syntactic constructions, he subdivides substantives into classified nouns (nouns which are directly preceded by a classifier) and nonclassified nouns (nouns which do not have a classifier), classifiers, numerators, demonstrative numerators, personal and place names, and pronouns. He distinguishes three types of substantive phrases which are referred to respectively as numeration, attribution and addition. According to Emeneau (Ibid.), a numeration substantive phrase is one in which the noun is preceded by a numerator as hai (two) in hai cuốn sách (two books) or followed by a demonstrative numerator as đầu (tiên) (first) in cuốn sách đầu (the first book), or both as hai (two) and đầu (first) in hai cuốn sách đầu (the first two books), with a classifier; e.g. cuốn, immediately preceding the noun if the latter belongs to the subclass called classified. An attribution substantive phrase is one in which the noun, whether numerated or not, is immediately followed by an attribute or attributes, which may be noun, numerator (rarely), pronoun, personal name (rarely), verb or verb phrase, or complete predication (sometimes introduced by $m a \grave{~ . . .) ; ~ e . g . ~} m o ̂ t t$ cuốn sách hay (an interesting book). And an addition substantive phrase is one in which the head is an additive series of nouns or pronouns, usually without a co-ordinating conjunction; e.g. thày mẹ (father and mother) (for more detail, see Emeneau, 1951, p. 45; pp. 84-87). The order of elements in 'numeration constructions' can be represented in Table 3 .

Table 3. Order of elements in numerated constructions in Vietnamese (Emeneau 1951, p. 84)

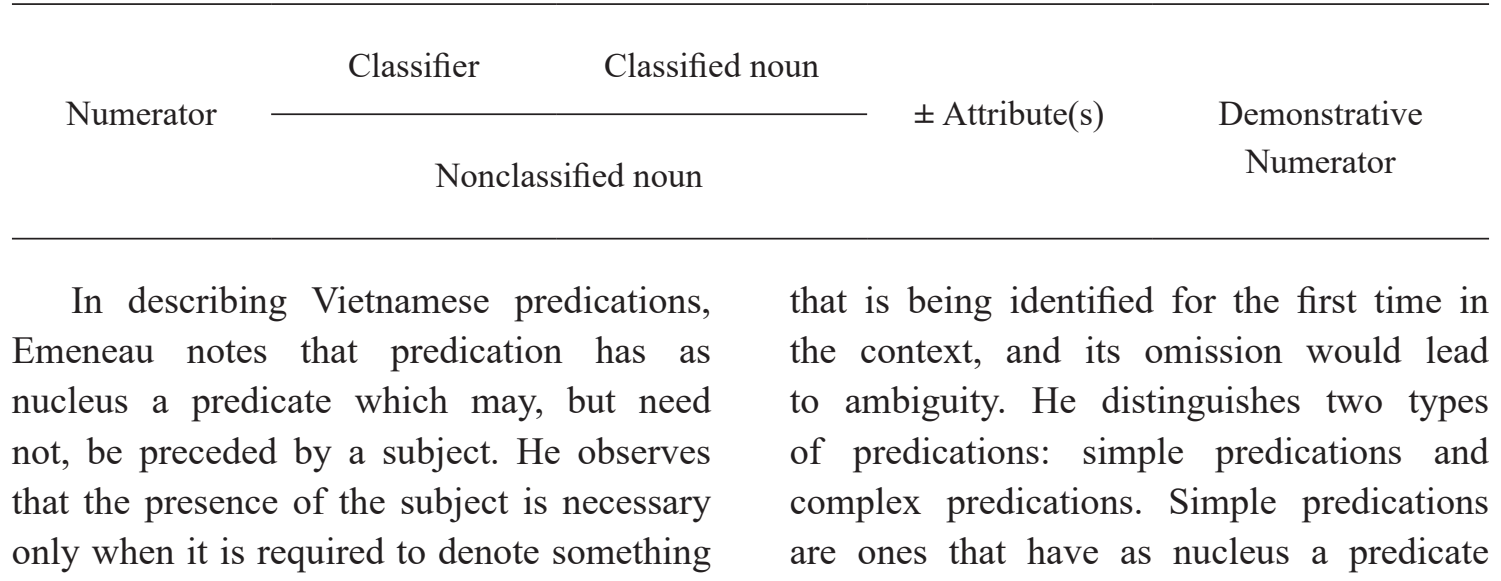


which may, but need not, be preceded by a subject (p. 46). Emeneau observes that it is impossible to determine exactly when a subject occurs, when it does not. He argues that its occurrence seems to be a matter of optional "selection". But when it occurs, the subject is normally a one-word substantive or a substantive phrase. Predicates are of two types: substantive and verb. A substantive predicate consists of either a substantive or a substantive phrase. A verb predicate consists of a verb or a verb phrase. The class meaning is actor acts (p. 48). Emeneau discovers that in Vietnamese substantive predicates are rarer than verb predicates. Complex predications are presented by Emeneau as follows: "within the same sentence, a single predication of any type is preceded by a substantive or substantive phrase, a verb or phrase or a predication with subject and verb predicate" (p. 54). The first member is called the subordinate, the second member is the main predication. In writing, there is usually a comma between these two members, although it is optional when the subordinate member consists of one word. Frequently the main predication has the conjunction thi as its first word; e.g. Giao nầy khó món phòng lắm. Phải cho hay trước vài ba ngày thì may ra mói có, vì người đông quá (At this time, it is very difficult to rent a room. You have to inform them a few days beforehand and by good luck you may get one, because there are very great crowds of people) (p. 57). The two types of predications in Emeneau's formulation can be shown in Table 4.

Table 4. Formulas of simple and complex predications in Vietnamese (Emeneau, 1951, p. 61)

(S) $\quad \mathrm{V}(\mathrm{S})^{\mathrm{n}}$. Simple predications $(\mathrm{P})$

$$
\text { S. }
$$

$\mathrm{V}(\mathrm{S})^{\mathrm{n}} \mathrm{S}$.

Complex predications

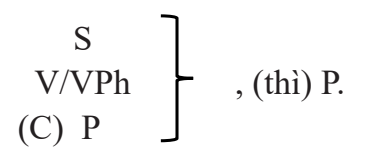

Note: $\mathrm{P}=$ predication; $\mathrm{S}=$ substantive or substantive phrase; $\mathrm{V}=$ verb, $\mathrm{VPh}=$ verb phrase; $\mathrm{C}=$ coordinate conjunction; () indicates optional presence of that which is enclosed; ${ }^{\mathrm{n}}$ indicates one or more occurrences in series.

Based on these general observations, Emeneau continued to explore other issues related to complex predications such as complex equational predications, predications connected by coordinating conjunctions, notes on 'tense' and 'voice' and order in verb series in Vietnamese. In complex equational predications, Emeneau observes, the verb is to balance the subject with its object; for example, Cleanliness is the mother oflong life (p. 61). In predications connected by coordinating conjunctions,
Emeneau does not provide any explanation but instead he gives some examples for illustration; one of those examples is $K h i$ đi tôi đã nhắc anh rồi, và tôi đã thấy anh cầm chìa khoá (When we went, I reminded you and I saw you take the key) (p. 63). In discussing expressions that are related to the categories of tense and voice in IndoEuropean languages, Emeneau remarks:

The point to be made, however, is that verbs do not carry the categories of tense and mode. 
These, to some extent, are carried by the sentence construction, but to an even greater extent they are left to the extragrammatical context, linguistic or nonlinguistic. (Emeneau, 1951, p. 63)

Sharing Yuen Ren Chao's (1968) view on verbs in Chinese and carefully examining the operation of verbs in Vietnamese, Emeneau affirms:

Tense, mode, and voice, then, are not categories of the Vietnamese verb, nor are aspect, and number and person of the subject or object. The verb has as its class meaning: it occurs or can occur as the nucleus of a predicate and cannot occur as the subject of a predicate or as the object of a verb, except when the verb of the predicate is là. (Emeneau, 1951, p. 63)

Apart from examining a number of single verbs by explaining their meanings and giving examples in which they occur, Emeneau explores the order of different types of verb in the series. The results are presented in Table 5.

Table 5. The first order in a verb series in Vietnamese (Emeneau, 1951, p. 74)

\begin{tabular}{ccccc}
\hline 1 & \multicolumn{2}{c}{2} & 3 & $4 \ldots$ \\
\hline cũng & $\begin{array}{c}\text { sẽ } \\
\text { đã }\end{array}$ & $\begin{array}{c}\text { chớ / đừng } \\
\text { không / chẳng }\end{array}$ & tự & $\ldots \ldots$ \\
\hline \multicolumn{2}{c}{ chưa } \\
\hline
\end{tabular}

According to Emeneau, sẽ and $d \tilde{a}$ are assigned to the subclass of 'time verbs', and chẳng, chó, đùng and không (which are actually negative words) to the subclass of 'negative verbs'. He explains that sẽ can precede chó, đù̀ng, không, chẳng, while đã can precede only không and chẳng; chura can neither precede nor follow any element within 'order 2' (for more details on these points, see Emeneau, 1951, p. 74).

With regard to the description of pronouns (Chapter III), morphemes restricted in use (Chapter V), conjunctions (Chapter VI), final particles (Chapter (VII), and interjections (Chapter VIII) in Vietnamese, Emeneau does not have much to offer. Like the French scholars who studied Vietnamese grammar (e.g. Aubaret, 1864; Bouchet, 2012; and Cordier, 1930; Grammont and Le Quang Trinh, 1911; Léon, 1885; Vatlot, 1897), he divides pronouns in Vietnamese into two main categories: (i) personal pronouns and status pronouns and (ii) designative pronouns and questionable pronouns. These types of pronouns are examined by giving examples in which they occur. Emeneau's description of morphemes restricted in use in Vietnamese is based primarily on the Vietnamese-French dictionary entitled Dictionnaire annamitefrancais à l'usage des élèves des écoles et des annamitisants by the French lexicographer Cordier (1930).

\section{Laurence C. Thompson}

Following Emeneau's Studies in Vietnamese (Annamese) Grammar, several other American linguists continued to show interest in studying Vietnamese grammar. Most notable of them all was perhaps Dr. Laurence C. Thompson - a polyglot, a descriptivist and comparativist credited with contributions in Vietnamese and Salish languages. Thompson's entry into Vietnamese in his career was fortuitous. It was prompted by his opportunity to join an areal programme. He did a two-year field work in Vietnam for 
his doctoral dissertation entitled A Grammar of Spoken South Vietnamese which was defended in 1954. He taught Vietnamese language at Yale for one year and then for two years at the Defense Language Institute at the Presidio of Monterey, California. Thompson's A Vietnamese Grammar was first published in 1965. In 1985 it was published by the University of Hawaii Press under the title A Vietnamese Reference Grammar.

\section{A Vietnamese Reference Grammar} can be divided into four main parts. Part I is from Chapter 1 to Chapter 4, in which Thompson introduces general features of Vietnamese phonetics, pronunciation and tones (Chapter 1), basic characteristics of the phonological system of Hanoi dialect - a Vietnamese dialect Thompson took as the main object of description (Chapter 2), basic characteristics of the writing systems through different periods of time (Chapter 3), and dialectal variations of Vietnamese (Chapter 4). Part II extends from Chapter 4 to Chapter 11. It is concerned with grammatical structure of Vietnamese language. Here Thompson examines and clarifies instrumental concepts from the morpheme to the sentence to establish a theoretical framework to describe grammatical structures of Vietnamese language (Chapter 5), characteristics of compounds and pseudo-compounds (Chapter 6), characteristics of derivatives (Chapter 7), substantive elements (Chapter 8), predicative elements (Chapter 9), focal elements (Chapter 10), and particles (Chapter 11). Part III is devoted to exploring the sentence structure in Vietnamese (Chapter 12). Here Thompson examines in detail syntactic concepts such as sentences, clauses, unmarked main clauses, main clauses marked coordinate particles, main clauses marked with isolating particles, and some other grammatical concepts. And Part IV deals with linguistic style.
Here Thompson explores issues of what he calls the "levels of discourse", address and reference, kinship system, polite address and reference, honorific address and reference, conversational style, and scholarly style (Chapter 13). In addition, Thompson devotes an entire chapter (Chapter 14) to discussing lexical complexities commonly found in Vietnamese language such as indefinite words, negation, units of measure, etc.

Like most grammarians of Vietnamese, whether foreign or indigenous, who were inspired by the American descriptivist/ structuralist tradition (e.g. Gage and Jackson, 1953; Nguyen Dinh Hoa, 1957a, 1957b; and others), Thompson employs immediate constituent analysis as the main method in his A Vietnamese Reference Grammar for isolating components of the sentence as well as constituents of each component. According to Thompson, an utterance is analysed into two or more parts which balance one another in the make-up of the whole. Each of these parts is then subjected to similar analysis, and so on until the level of single morphemes is reached and no further grammatical/morphological division can be made. Here we find linguistic terms and concepts which are defined from the descriptivist/structuralist perspective such as morpheme, word, phrase, construction, sentence, clause, model, head, complement and others. Thus following the mainstream Bloomfieldian position (Bloomfield, 1933), for Thompson too the smallest building block is the morph: it is a component which carries an identifiable meaning recognisable as contributing to the meaning of the whole utterance and contains no smaller meaningful bits which can be said to make such a contribution. Proceeding from this definition of morph, a morpheme is seen as the class of all morphs having precisely the same meaning (p. 105). 
Words, in Thompson's definition, are single free morphemes and/or basic free morphemes (p. 118) or the minimum freely distributed units of which sentences are composed (p. 116). Words can be either simple or complex, independent or dependent (for more detail, see Thompson, 1985, pp. 118-9). Phrases are constituents consisting of more than one word (p. 123). Constructions are phrases which have the same arrangement of heads and complements (p. 123). There are three types of construction: (i) coordinating, (ii) subordinating, and (iii) mixed. A co-ordinating construction is one which forms phrases with more than one head; a subordinating construction is one which forms phrases with only one head; and a mixed construction is one which is basically co-ordinating (i.e., it forms phrases with more than one head) but which also has a complement. Subordinating constructions can be either restrictive (forming phrases with the order of head-complement) or descriptive (forming phrases with the order of complement-head). A sentence is a sequence of one or more groups ending with a terminal intonation and preceded by silence or by another such sequence. In printed material, a sentence may be marked with a capital letter at the beginning and a period, a question mark, or exclamation point at the end (pp. 111, 277). Sentences, according to Thompson, are of two types: independent and dependent sentences. Independent sentences are those that appear as opening sentences in independent utterances. In contrast, dependent sentences are those that appear only as the second or later sentences in utterances or as opening sentences in responsive utterances. Thompson observes that the structure of sentences is not the same: there are sentences which consist of only one clause; and there are other sentences which consist of a series of clauses of which at least one clause is the head. He calls this clause major clause and the others minor clause (p. 277).
Aclause, in Thompson's view, is a predicate (together with any complement it may have) viewed as a sentence constituent (p. 277). For Thompson, each time a predicate occurs, from the point of view of the sentence in which it stands, it is a clause (or if the sentence has complements, the head is a clause). Like other sentence elements, a clause is sometimes head and sometimes complement. When a clause occurs as head or as the whole of a certain sentence, it is the main clause. Conversely, when a clause appears as complement to other sentence elements, it is a subordinate clause. Subordinate clauses are further classified as descriptive (following the head) and restrictive (preceding the head) (for more detail, see Thompson, 1985; Chapter 12).

Having established the above terms and concepts, Thompson defines the terms 'model' and 'expansion' as follows:

The syntactic structure of any language is observable as a relatively small number of patterns in each of which the elements (although consisting of infinitely varied morpheme sequences) bear the same basic relationship to one another. Longer sequences are seen to have the same function as far shorter sequences - that is, a longer sequence bears the same relationship to its immediate constituent partner as a shorter sequence in the same position. This is conveniently described by saying that the shorter sequence is the model of the longer one, and that the longer one is an expansion of the shorter one. (Thompson, 1985, p. 111)

Thompson provides some examples to illustrate his definition. One of them is the English sentence John's brother is playing tennis. Employing the method of immediate constituent analysis, the sentence is segmented into two parts: (i) John's brother and (ii) is playing tennis. Thompson says that 
a model for John's brother is Jim, as in Jim is playing tennis. Similarly, a model for is playing tennis is works, as in John's brother works. Conversely, John's brother and is playing tennis are expansions respectively of Jim and works. Thompson observes that often in Vietnamese one of the immediate constituents of a particular constitute is a model of that constitute. He terms such constitute a 'nuclear model' and defines it as 'an immediate constituent which can replace its constitute in the larger context, remaining the same basic grammatical and referential relationship to that context'. Proceeding from this definition, Thompson defines heads as nuclear models of the constitutes which are themselves either nuclear models or complete sentences, and complements as non-model partners of heads. The analysis into model, head, and complement can be illustrated by the following example:

Ngày xưa có người hiếu-lợi model, head

Ngày xura complement ngày (day) xua (in former times) có người hiếu-lợi có (exist) người hiếu-lợi: người (person) hiếu-lơi (be greedy) hiếu (be fond of) lợi (profit)

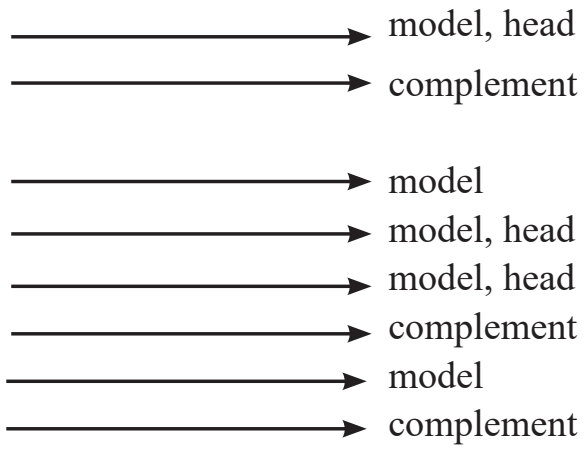

(Based on Thompson, 1985, p. 114)

As can be seen, although Thompson uses different terminologies in his framework, his analysis is similar to the immediate constituent analysis technique employed by post-Bloomfieldian scholars such as Gleason (1955), Harris (1951), and Hockett (1958) in relation to English, and Honey (1956) in relation to Vietnamese.

There are substantial differences between A Vietnamese Reference Grammar (1985) as compared with his A Grammar of Spoken South Vietnamese (1954), and Việt-Nam Văn-Phạm (A Grammar of Vietnamese) by Tran Trong Kim et al. (1940). Whereas in A Grammar of Spoken South Vietnamese (1954), Vietnamese words are explicitly divided into six major classes; viz., aspects, verbals, relators, numerators, substantives, and particles, in A Vietnamese Reference Grammar, they are grouped into four major categories which are termed (i) substantival elements, (ii) predicative elements, (iii) focal elements, and (iv) particles. In each of these headings, based on the relationship between head and complement in the construction and the position in which a word and an element occurs, words are further subdivided and thoroughly discussed (for more detail, see Thompson, 1985; Chapters 8, 9, 10, 11). And unlike Việt-Nam Văn-Phạm (A Grammar of Vietnamese) by Tran Trong Kim et al. (1940) in which word classes or parts of speech are identified based on both definition (meaning) and recognition (form) criteria; in A Vietnamese Reference Grammar, words are identified based primarily on their recognition criteria. For example, when analysing 
substantive elements, Thompson states: "There are two sets of markers which help identify substantive elements. They are plural markers (appear as restrictive complements)

\section{PLURAL MARKERS}

nhüng (plural)

các (plural) (all of a given set)

mọi (every)

mối (each)

tù̀ng (each) (in turn)

From these different approaches to word classification, one can see the difference between what Halliday (1978) and Halliday and Hasan (1989) refer to as 'tenor of discourse' of Việt-Nam Văn-Phạm and A Vietnamese Reference Grammar: while the former work is written to serve one type of audience - learners of Vietnamese grammar, the latter seems to address various kinds of audience. In other words, while Việt-Nam Văn-Phạm can be considered a pedagogical grammar, A Vietnamese Reference Grammar, as its name stands, can be considered a reference grammar, hence its title.

(1) Nhà cháy rồi.

(The house has burned already.)

(2) Cái cột đồng ấy nay đã mất mà Tây-hồ vẫn còn. [nominal group, object] (p. 240)

(That bronze pillar today is lost, but West Lake still exists.)

(3) Ở bên nam nóng lắm.

(In the South, it's very hot.)

(4) Nói phải có người nói đi nói lại chớ bắt người ta nói một mình hoài!

(For a conversation [you] ought to have people talking back and forth, not make somebody talk alone all the time!)

With the advantage of a linguist who knows many foreign languages, Thompson displays a keen observation of the order, structure and ways of recognizing focal elements in the sentence. He discovers that on many occasions, focal elements are marked by a restrictive subordinating particle such as nếu (if), vì (because), and more frequent [verb, predicate] (p. 241)

and demonstrative markers (appearing as descriptive complements)" (p. 179). Then he provides two lists to illustrate these two sets of plural and demonstrative markers:

\section{DEMONSTRATIVE MARKERS}

nào (which [ever])

này (this)

no (that, [an] other)

ấy ([the one] just referred to)

nấy (this [one] just mentioned)

Focal elements in Vietnamese sentences are probably one of the most original treatments in Thompson's A Vietnamese Reference Grammar (Cao Xuan Hao, 1991, 2004). Thompson observes that focal construction forms restrictive phrases with predicates as head. In terms of word classes, a focal element can be either a substantive, a substantival phrase or (even) a predicate. In terms of size, a focal element can be either a single word, a word group, or a phrase. And in terms of syntactic function, a focal element can be subject, predicate, object, or adverbial modifier. Below are some of the examples provided by Thompson.

[substantive, subject] (p. 239)

is the marking of the head of a focal phrase by what he calls 'isolating particle' thi (then) as in Rùng thì rậm, đường lối đi lại thì khó khăn (The forest was dense, the routes of communication difficult) (p. 244).

According to Thompson, focal elements can be either simple or complex. He observes that focal complexes show elements in certain 
consistent order. They are of three main types:

(i) those displaying the relative order of manner-time-place-topic (bolds in original), (ii) those in which outer complements are more general and inner complements are more Type (i)

\begin{tabular}{|c|c|c|c|c|}
\hline $\begin{array}{l}\text { Nhu thế } \\
\text { manner }\end{array}$ & $\begin{array}{l}\text { hôm qua } \\
\text { time }\end{array}$ & $\begin{array}{l}\text { tại cho } \\
\text { place }\end{array}$ & $\begin{array}{l}\text { tôi } \\
\text { topic }\end{array}$ & mua nhiều đồ. (p. 244) \\
\hline
\end{tabular}

(So it was that yesterday at market I bought a lot of things.)

Type (ii)
Ông ấy
Outer complement
tánh
inner complement
(He's of a happy disposition.)
Type (iii)

ua sung-suoóng. (p. 245)

\section{Đi Sài-gòn,}

\section{Outermost complement}

tôi đi mỗi tuần ba lần. (p. 245)

(As for going to Saigon, I go three times every week.)

It is interesting to note that the functions of the elements which Thompson calls 'specialising focal complexes' in examples (i), (ii), and (iii) above have also been recognized and discussed by grammarians of Vietnamese. Truong Van Chinh and Nguyen Hien Le (1963), for example, refer to Đi Sài-gòn, tôi in Type (iii) as 'chủ đề' (topic) and 'chủ ngữ' (subject) respectively; Hoang Trong Phien (1980) and UBKHXH (1983) refer to them as 'thành phần đài lên đầu câu' (sentence-initial element) and 'chủ ngữ' (subject); and Diep Quang Ban (1987, 2005) calls them 'khởi ngữ' (sentence-initial phrase) and 'chủ ngữ' (subject). However, among the grammarians of Vietnamese who have examined this issue, Thompson seems to have offered the most original treatment. His treatment is similar to the approach of the Prague school scholars, particularly of systemic functional linguistics scholars who see the clause as a message consisting of Theme and Rheme in which the Theme is the point of departure of the message; it can be any element of the clause that occupies initial position in the clause: subject, predicate, complement, or adjunct; and it can be single (one element) or multiple (more than one elements) (Halliday, 1998; Halliday and Matthiessen, 2014).

Regarding Vietnamese sentence structure, Thompson's description does not contain much innovation. He starts his $A$ Vietnamese Reference Grammar by describing the units sentence and clause - a common approach to grammatical description found in many grammar books of other languages. Sentences are divided into major and minor sentences. Clauses are divided into unmarked main clauses and main clauses marked by coordinating particles, main clauses marked by isolating particles, descriptive clauses, and restrictive clauses. In addition, he devotes a small section to discussing emphatic positions in the sentence. Thompson observes that initial position and final position seem to be more emphatic than others. This is because "initial position commands first attention to the hearer or reader; final position has the advantages of leaving its content as the most recent impression of the audience, of reserving a conclusion until after a case is stated, or of 
conserving and element of surprise while the circumstances are built up" (p. 290). Below are two examples to illustrate Thompson's point:

Cái nầy tiếng Việt gọi chi? (p. 290)

(What is this called in Vietnamese?)

Nàng vì cảm động, không giư được nỗi thổn thức, oà lên khóc. (p. 290)

(The girl, because she was deeply moved, was unable to withstand a disturbing emotion [and] burst into tears.)

\section{Concluding remarks}

In this paper, we have made an attempt to explore the contributions made by American descriptive linguistic school to the study of Vietnamese. Two representative grammar monographs on Vietnamese grammar by two foremost American grammarians in the middle and the second half of the $20^{\text {th }}$ century were taken for examination: Studies in Vietnamese (Annamese) Grammar by Murray Emeneau and A Vietnamese Reference Grammar by Laurence C. Thompson. We can now say a few words of appraisal about their works in answer to the questions raised in the Introduction: "How is Vietnamese anatomized by grammarians of American descriptive linguistic school?", and "What contributions do they make to the description of Vietnamese grammar?"

Emeneau's Studies in Vietnamese (Annamese) Grammar is a commendable attempt to describe Vietnamese language from an approach different from the traditional structuralist approach to language prevalent in Europe in the second half of the $20^{\text {th }}$ century. However, different from many grammarians of Vietnamese in his time, he seems to be a theory user rather than a theory developer. This can be seen in the fact that the concepts he uses as the tools for analysing Vietnamese are not explicitly defined. They are often taken for granted and are used as if they were known to the reader. Further, different from other descriptive works on Vietnamese, Studies in Vietnamese (Annamese) Grammar is precisely written for foreigners studying Vietnamese. Reading Studies in Vietnamese (Annamese) Grammar readers may have a feeling that they are reading a mixture of a dictionary and a grammar book of Vietnamese. But if this is really the goal of the book, it can be affirmed that Studies in Vietnamese (Annamese) Grammar has fulfilled its goal: the learner of Vietnamese not only knows the word, its sound and spelling form and its meaning(s) but also how it is used in sentences - the context which the British linguist Catford (1965) refers to as 'linguistic context'. Studies in Vietnamese (Annamese) Grammar is a detailed and meticulous description of Vietnamese grammar, particularly of words and their usage.

Thompson's A Vietnamese Reference Grammar has provided invaluable insights into the phonological, lexical, and syntactic structures of Vietnamese in both theoretical and practical dimensions. Unlike Emeneau's Studies in Vietnamese (Annamese) Grammar, Thompson's A Vietnamese Reference Grammar does not explore in detail Vietnamese words and their usage. It is not at all an applied linguistic work either. Rather, it is a descriptive work which strikes in a systematic way a balance between theory and practice: it both examines in some detail the underlying concepts for the description of Vietnamese and provides examples to illustrate them. It is a grammar work which meets most of the criteria of a standard reference grammar such as meticulousness, comprehensiveness, lucidity, rigour, and elegance. This is, perhaps, the most comprehensive work of Vietnamese grammar which has ever been described in the American descriptivist tradition. It explains why "when it first appeared in 1965, it went almost instantly to the top of the list of required reading for serious students of the Vietnamese language", and "it 
remains far and away the best thing available in English and thus, the most useful work for the greatest number of potential users" (Nguyen Dinh Hoa, 1985, p. xiii).

On the whole, although Emeneau's and Thompson's books were published at different times and the range of topics they treat is not always the same, they both make a major point in seeking to analyse Vietnamese on the basis of Vietnamese alone, trying to avoid any distortion from Indo-European grammatical concepts. This has produced good results. Their books are well-written, well-exemplified on Vietnamese phonology, morphology and syntax. This explains why until now Studies in Vietnamese (Annamese) Grammar and $A$ Vietnamese Reference Grammar have had no rival in English, and are likely to remain the standard references on Vietnamese for quite a few years to come. In conclusion, Emeneau and Thompson have offered a quite fruitful approach to the description of Vietnamese. Their views of language description may spark further debates, but they will certainly lead to further advances in the analysis of language. Together with the studies of Vietnamese grammar by grammarians of other linguistic traditions, either indigenous or foreign, their works have enriched our ways of looking at language, broadening our understanding of one of the most fruitful approaches to the study of Vietnamese grammar (for detail, see Hoang Van Van, 2007).

\section{References}

\section{Vietnamese}

Diệp Quang Ban (1987). Câu đơn tiếng Việt [The Simple Sentence in Vietnamese]. Hà Nội: Nhà xuất bản Giáo dục.

Diệp Quang Ban (2005). Ngũ pháp tiếng Việt [A Grammar of Vietnamese]. Hà Nội: Nhà xuất bản Giáo dục.

Nguyễn Tài Cẩn (1975a). Tù loại danh tù trong tiếng Việt hiện đại [Nouns in Modern Vietnamese]. Hà Nội: Nhà xuất bản Khoa học xã hội.
Nguyễn Tài Cẩn (1975b). Ngũ pháp tiếng Việt: Tiếng - Tù ghép - Đoản ngũ [Vietnamese: Words, Compounds, and Phrases]. Hà Nội: Nhà xuất bản Đại học và Trung học chuyên nghiệp.

Trương Văn Chình, \& Nguyễn Hiến Lê (1963). Khảo luận vềngũ pháp Việt Nam [A Treatise of Vietnamese Grammar]. Huế: Đại học Huế.

Phạm Tất Đắc (1950). Phân tích tù loại và phân tích mẹnh đề [Word Class and Clause Analysis]. Sài Gòn: Nhà xuất bản $\mathrm{ABC}$.

Cao Xuân Hạo (1991). Tiếng Việt: So thảo ngũ pháp chúc năng [Vietnamese: An Outline of Functional Grammar] (Quyển 1). Hà Nội: Nhà xuất bản Khoa học xã hội.

Cao Xuân Hạo (2004). Tiếng Việt: So thảo ngũ pháp chíc năng [Vietnamese: An Outline of Functional Grammar]. Hà Nội: Nhà xuất bản Giáo dục.

Nguyễn Đình Hoà (1985). Editor's Note. Trong L. C. Thompson (Ed.), A Vietnamese Reference Grammar (xiii-xiv). Honolulu: Nhà xuất bản Đại học Hawaii.

Trần Trọng Kim, Bùi Kỷ, \& Phạm Duy Khiêm (1940). Việt-Nam Văn-Phạm [A Grammar of Vietnamese] (tái bản lần thứ tám). Sài Gòn: Nhà xuất bản Tân Việt.

Hoàng Trọng Phiến (1980). Ngũ pháp tiếng Việt: Câu [A Grammar of Vietnamese: The Sentence]. Hà Nội: Nhà xuất bản Đại học và Trung học chuyên nghiệp.

Robins, R. H. (2012). Lược sủ ngôn ngũ hoc [A Short History of Linguistics] (Hoàng Văn Vân, Trans.). Hà Nội: Nhà xuất bản Đại học Quốc gia Hà Nội.

Nguyễn Kim Thản (1977). Động tù trong tiếng Việt [Verbs in Vietnamese]. Hà Nội: Nhà xuất bản Khoa học xã hội.

Nguyễn Trúc Thanh (1956). Văn phạm mói giản dị và đầy đủ [A New Simple and Comprehensive Grammar]. Sài Gòn: Liên-Hiệp.

Bùi Đức Tịnh (1952). Văn phạm Việt Nam [A Grammar of Vietnamese]. Sài Gòn: Nhà xuất bản Phạm Văn Tươi.

Hoàng Văn Vân (2007). Từ Emeneau đến Thompson: Một chặng đường nghiên cứu tiếng Việt ở Mỹ [From Emeneau to Thompson: A Period of Studying Vietnamese in the USA]. Trong Nguyễn Thiện Giáp (Ed.), Lược sư Việt Ngũ [A Short History of Vietnamese Linguistics] (tập 2, tr. 457-76). Hà Nội: Nhà xuất bản Giáo dục.

UBKHXH (Uỷ ban Khoa học Xã hội) (1983). Ngũ pháp tiếng Việt [A Grammar of Vietnamese]. Hà Nội: Nhà xuất bản Khoa học xã hội.

\section{English}

Bloomfield, L. (1933). Language. New York: Holt, Rinehart and Winston.

Boas, F. (Ed.). (1911). Handbook of American Indian Languages (Part 1). Washington: Government Print Office.

Catford, C. J. (1965). A Linguistic Theory of Translation. Oxford: Oxford University Press. 
Chao, R. Y. (1968). Language and Symbolic Systems. Cambridge: Cambridge University Press.

Davis, P. W. (1973). Modern Theories of Language. Englewood Cliffs, NJ: Prentice Hall.

Emeneau, M. B. (1951). Studies in Vietnamese (Annamese) Grammar. Berkeley and Los Angeles: University of California Press.

Gage, W.W., \& Jackson, M.H.(1953). Verb Constructions in Vietnamese. Ithaca, NY: Department of Far Eastern Studies, Cornell University.

Gleason, H. A. (1955). An Introduction to Descriptive Linguistics. New York: Holt, Rinehart and Winston.

Halliday, M. A. K. (1978). Language as Social Semiotic: The Social Interpretation of Language and Meaning. London: Edward Arnold.

Halliday, M. A. K. (1998). An Introduction to Functional Grammar (2nd ed.). London: Arnold.

Halliday, M. A. K., \& Hasan, R. (1989). Language, Context, and Text: Aspects of Language in a Socialsemiotic Perspective. Oxford: Oxford University Press.

Halliday, M. A. K., \& Matthiessen, C. M. I. M. (2014). An Introduction to Functional Grammar (4th ed.). London and New York: Routledge.

Harris, Z. S. (1951). Structural Linguistics. Chicago: The University of Chicago Press.

Hoang, V. V. (2012). An Experiential Grammar of the Vietnamese Clause. Hanoi, Vietnam: Vietnam Education Publishing House.

Hockett, C. F. (1958). A Course in Modern Linguistics. New York: The Macmillan Co.

Honey, P. J. (1956). Word Classes in Vietnamese. Bulletin of the School of Oriental and African Studies, University of London, 18(3), 534-544.

Matthiessen, C. M. I. M. (1995). Lexicogrammatical Cartography: English Systems. Tokyo: International Language Sciences Publishers.

Nguyen, D. H. (1957a). Speak Vietnamese. Sai Gon, Vietnam: Publications of School of Languages.

Nguyen, D. H. (1957b). Classifiers in Vietnamese. Word, 13(1), 124-152.

Robins, R. H. (1997). A Short History of Linguistics (4th ed.). London and New York: Longman.
Sampson, J. (1980). Schools of Linguistics: Competition and Evolution. London: Hutchinson.

Spolsky, B. (1997). The Impact of the Army Specialized Training Program: a reconsideration. In G. Cook \& B. Seidlhofer (Eds.), Principle and Practice in Applied Linguistics: Studies in Honour of $H$. G. Widdowson (pp. 323-334). Oxford: Oxford University Press.

Thompson, C. L. (1954). A Grammar of Spoken South Vietnamese. Doctoral dissertation, Yale University.

Thompson, C. L. (1965). A Vietnamese Grammar. Seattle: University of Washington Press.

Thompson, C. L. (1985). A Vietnamese Reference Grammar. Mon-Khmer Studies Journal, 13-14, $1-367$.

\section{French}

Aubaret, G. (1864). Grammaire de la Langue Annamite. Paris: Imprimerie impériale.

Bouchet, A. (1912). Cours Elementaire D'annamite. Hanoi and Haiphong: Imprimerie d'Extrême-Orient.

Cordier, G. (1930). Dictionnaire annamite-francais à l'usage des élèves des écoles et des annamitisants. Hanoi: Imprimerie Tonkinoise.

Grammont, M., \& Le, Q. T. (1911). Études sur la Langue Annamite. In Mémoires de la Société de Linguistique de Paris (Vol. 17). Paris: Imprimerie Nationale.

Le, V. L. (1948). Le Parler Vietnamien: Sa Structure Phonologique et Morphologique Fonctionnelle. Paris: Hoàng Anh.

Léon, R. (1885). Notice sur la Langue Annamite. Paris.

Vallot, P. G. (1897). Grammaire Annamite: à l'usage. (Des Francais de L'annam et du Tonkin). F-H. Schneider, Imprimeur-Éditeur.

\section{Russian}

Солнцев В. М., Лекомцев Ю. К., Мхитарян Т. Т., Глебова И. И. (Solntsev V. М., Lekomtsev YU. K., Mkhitaryan T. T., Glebova I. I) (1960). Вьетнамский язык (The Vietnamese Language)/ Отв. ред. В. М. Солнцев. Москва: Издательство восточной литературы. 


\title{
NHŨ’NG ĐÓNG GÓP CỦA TRƯờNG PHÁI NGÔN NGƯ⿱ HOC MÔ TẢ MĨ VÀO NGHIÊN CÚU TIẾNG VIẸT: MỘT CÁI NHİN ĐƯƠNG ĐẠI
}

\author{
Hoàng Văn Vân \\ Trung tâm Nghiên cứu giáo dục ngoại ngũu, ngôn ngũ và quốc tế học \\ Truoòng Đại hoc Ngoại ngũ, ĐHQGHN, \\ Phạm Văn Đồng, Cầu Giấy, Hà Nội, Việt Nam
}

Tóm tắt: Bài viết này nghiên cứu những đóng góp của trường phái ngôn ngữ học mô tả của Mĩ ở những năm giữa thế kỉ 20 vào nghiên cứu về tiếng Việt. Hai chuyên khảo quan trọng nhất về ngữ pháp tiếng Việt của hai nhà ngữ pháp mô tả/cấu trúc hàng đầu người Mĩ được chọn ra để nghiên cứu: Studies in Vietnamese (Annamese) Grammar (Nghiên cứu về ngữ pháp tiếng Việt) của học giả Murray B. Emeneau và A Vietnamese Reference Grammar (Ngữ pháp tham khảo tiếng Việt) của học giả Laurence C. Thompson. Rõ ràng là trong số các học giả nước ngoài nghiên cứu tiếng Việt, Emeneau và Thompson đã có những đóng góp đáng kể nhất vào nghiên cứu ngữ pháp tiếng Việt. Cả hai ông đều có chung một điểm quan trọng trong việc tìm cách phân tích tiếng Việt trên cơ sở từ bên trong tiếng Việt, cố gắng tránh càng nhiều càng tốt bất kì sự lệch lạc nào từ các khái niệm ngữ pháp Ân-Âu; và do đó đã tạo ra các kết quả tốt và đáng tin cậy. Công trình mô tả của hai ông về ngữ pháp tiếng Việt rất chi tiết và có hệ thống; đáp ứng được hầu hết các tiêu chí của một công trình ngữ pháp chuẩn mực: tỉ mỉ, toàn diện, mạch lạc, chính xác, và tao nhã. Cùng với các công trình nghiên cứu về ngữ pháp tiếng Việt của các nhà ngữ pháp khác, cả người Việt Nam và người nước ngoài, công trình ngữ pháp của Emeneau và Thompson đã làm phong phú cách nhìn của chúng ta về ngôn ngữ, mở rộng sự hiểu biết của chúng ta về một trong những cách tiếp cận hiệu quả nhất đối với việc nghiên cứu ngữ pháp tiếng Việt.

Tù khóa: trường phái ngôn ngữ học mô tả của Mĩ, tiếng Việt, ngữ pháp tiếng Việt, Murray B. Emeneau, Laurence C. Thompson. 